\section{A caminho do paraíso: Galdino do Valle Filho e o projeto liberal burguês na Nova Friburgo republicana}

On the way to paradise: Galdino do Valle Filho and the bourgeois prsoject in Nova Friburgo at the beginning of Brazilian republic

Ricardo da Gama-Rosa Costa

Mestre em História do Brasil pela Universidade Federal Fluminense

Rua Monsenhor Miranda, 131/202 Centro 28610-230 Nova Friburgo - RJ Brasil rcosta@netflash.com.br
COSTA, da G.-R.: 'A caminho do paraíso: Galdino do Valle Filho e o projeto liberal burguês na Nova Friburgo republicana'.

História, Ciências, Saúde - Manguinhos, Rio de Janeiro, vol. 9(1):79-104, jan.-abr. 2002.

Este artigo apresenta parte da história política de Nova Friburgo, cidade da região serrana do estado do Rio de Janeiro, a partir da trajetória do grupo liderado pelo médico Galdino do Valle Filho, durante a afirmação da ordem republicana no país, no início do século XX. O grupo de Galdino, associado à defesa dos interesses de industriais e comerciantes, elaborou uma visão de cidade "européia" e "civilizada", quando da instalação no município das primeiras fábricas têxteis, fundadas por empresários alemães. Na construção dessa imagem houve tensão entre privilegiar a formação de Nova Friburgo, ligada à colonização suíça no século XIX, ou reconhecer a forte presença germânica na cidade. É dessa época a formulação do "mito da Suíça brasileira", relacionada à luta pela hegemonia dos liberais. O mito acabou se firmando como contingência do processo histórico mundial, abalado pelas duas grandes guerras, nas quais a participação dos alemães ficou marcada como negativa. PALAVRAS-CHAVE: história política, ideologia e poder, mito da Suíça brasileira, Nova Friburgo na República, projeto liberal burguês.

COSTA, da G.-R.: 'On the way to paradise: Galdino do Valle Filho and the bourgeois project in Nova Friburgo at the beginning of Brazilian republic'. História, Ciências, Saúde - Manguinhos, Rio de Janeiro, vol. 9(1):79-104, Jan.-Apr. 2002.

The present article covers a period of the political bistory of Nova Friburgo, a city in the mountains of the state of Rio de Janeiro, during the consolidation process of Brazilian republic at the beginning of the twentieth century. It focus the political group led by Galdino do Valle Filho who defended industrialists' and traders' interests. They developed the image of a "European" and "civilized" city as German entrepreneurs were starting to run the first textile factories in the municipality. The building up of such image had to cope with the tension between Nova Friburgo's formation, as a city colonized by the Swiss in the nineteenth century, and the strong presence of German immigrants in the city then. It was at this time that the image "Brazilian Switzerland" was created as part of the bourgeoisie's strategy to achieve hegemony. In fact, the city, came to consolidate its identity due to a contingency in the world panorama, shaken up by two world wars, at the end of which German participation was considered negative.

KEYWORDS: History of politics, ideology and power, "Brazilian Switzerland", Nova Friburgo in the republic, bourgeois project 


\section{Introdução}

Ta década de 1980, o grupo político do então prefeito municipal Heródoto Bento de Mello desenvolvia a tese de que Nova Friburgo seria o "paraíso capitalista". Tal tese baseava-se no fato de que a iniciativa privada, identificada, basicamente, com diversas empresas que dominavam as principais atividades econômicas na cidade - as grandes fábricas têxteis e metalúrgicas, Rendas Arp, Ypu, Filó, Haga etc.; empresas ligadas ao comércio e ao turismo; a companhia de energia elétrica, formada por capital privado; a empresa de ônibus, detentora do monopólio na exploração das linhas municipais etc. não só representaria o motor principal do desenvolvimento econômico do município, mas seria responsável também pela garantia de um alto nível de vida à sua população.

A facção política liderada pelo engenheiro Heródoto Bento de Mello, empresário do setor da construção civil, representava os interesses dos grupos econômicos mais poderosos da cidade. Ou seja, os grandes empresários do comércio, os donos das principais fábricas têxteis e metalúrgicas e as firmas de construção civil, além de se apresentarem como a elite capaz de guiar Nova Friburgo no rumo do progresso dentro da ordem, pretendiam dar continuidade à liderança anterior do médico Galdino do Valle Filho, cuja ação política, nas décadas de 1910 e 1920, foi, em grande parte, responsável pela instalação das primeiras fábricas da cidade.

Galdino é identificado como o homem político que contribuiu de maneira decisiva para que Nova Friburgo viesse a se tornar uma cidadela avançada do 'progresso' e da 'civilização'. Sua vida política, interrompida em 1961, esteve associada a diversos movimentos políticos e sociais, como a defesa dos interesses do empresariado local e dos pressupostos liberais, a perseguição sofrida durante a revolução de 1930 e o Estado Novo, a fundação e liderança da União Democrática Nacional (UDN) nas décadas de 1940 e 1950 e a reconquista do poder municipal, com a eleição do engenheiro César Guinle, ao fim da ditadura varguista. Também partiu de seu grupo a maior contribuição em termos de ação política e do discurso ideológico, para edificar a imagem do município como a "Suíça brasileira".

Das visões construídas sobre Nova Friburgo, a que se firmou tornandose hegemônica remonta às origens históricas da cidade colonizada por alemães e pelos primeiros imigrantes europeus suíços trazidos por $\mathrm{d}$. João VI. Um processo de "tradições inventadas" contribuiu para a elaboração do mito da Suíça brasileira, colaborando para a idealização da imagem de uma cidade 'paradisíaca'. Segundo essa versão, em Nova Friburgo o trabalho escravo teria sido praticamente inexistente, proporcionando condições à formação de uma sociedade étnica e culturalmente mais 'civilizada', com a predominância da mão-de-obra livre e branca de origem européia. Seria uma cidade com características 
especiais, que a destacariam do restante do país 'atrasado' tanto cultural quanto economicamente, porque mestiço e preponderantemente da grande propriedade escravista. Os colonos europeus, apontados como amantes do trabalho árduo nas suas pequenas propriedades, teriam sido responsáveis pela formação de uma sociedade mais próxima dos padrões culturais 'avançados', mais próxima, portanto, da 'civilização' e do 'progresso' e mais distante do 'barbarismo' e do 'atraso' presentes na maioria das regiões brasileiras.

A construção de tal imagem não se fez sem lutas e tensões. Em primeiro lugar, a identificação de Nova Friburgo com a Suíça brasileira acabou esbarrando com luso-brasileiros, africanos, italianos, espanhóis e, sobretudo, alemães, que, com a presença em maior número no município, constituíam importante núcleo cultural e político, em virtude de serem os principais acionistas e diretores das fábricas. Sua influência nos destinos políticos da cidade constituiu-se muito mais evidente que a de qualquer outro grupo étnico, ao menos até o fim da Segunda Guerra Mundial. Não foi à-toa que os discursos associando Friburgo aos pioneiros suíços tornaram-se mais intensos nas conjunturas imediatamente posteriores às duas grandes guerras, quando a imagem dos alemães esteve profundamente abalada.

Outro foco de tensões foi a própria luta política municipal, que opunha a facção dos liberais aos representantes de interesses distintos dos seus, fossem aqueles que, nas décadas de 1910 a 1920, seguiam a liderança regional de Nilo Peçanha, de quem Galdino tornou-se intransigente adversário, fossem aqueles que, das décadas de 1930 a 1960, vincularam-se ao getulismo e ao chamado populismo. Essas manifestações políticas em Nova Friburgo tiveram a sua maior expressão no médico Amâncio Mário de Azevedo, que se projetou no cenário político municipal ancorado na imagem carismática do médico 'caridoso', que atendia sem cobrar os pacientes mais pobres.

Esse é o cenário do momento chave da história política de Nova Friburgo, quando se deu a origem dos embates político-ideológicos, em que, por meio da destacada atuação do médico Galdino do Valle Filho, começou a ser posto em prática, como parte dos interesses de uma burguesia liberal ascendente, um projeto modernizador para a cidade, acoplado à elaboração do mito da Suíça brasileira.

\section{Galdino do Valle Filho e o projeto liberal}

O médico Galdino do Valle Filho foi um dos principais responsáveis pela construção da imagem de Nova Friburgo como uma cidadela do 'progresso' e da 'civilização', erigida em meio ao 'atraso' dominante na maior parte das regiões do estado e do país, em virtude de sua formação social estar baseada principalmente no latifúndio escravocrata e na monocultura para exportação. A nova ordem capitalista e burguesa, emergente com a industrialização e o desenvolvimento urbano da 
virada do século XIX para o XX, iria encontrar, em Friburgo, junto ao grupo liderado por Galdino do Valle Filho, sua correspondente defesa em termos da propaganda ideológica e de um projeto 'progressista' efetivamente posto em prática com a instalação das primeiras fábricas na década de 1910. A afirmação e posterior consolidação desse projeto fez parte de uma estratégia política formulada e concretizada na luta travada pelo grupo para desbancar do comando político do município a facção dos grandes proprietários ligados à economia do café então decadente.

Durante todo o século XIX, a economia cafeeira foi responsável pelo desenvolvimento da região oriental do Vale do Paraíba do Sul, sob a liderança de Cantagalo. Nova Friburgo organizou sua economia como abastecedora dos gêneros necessários à região e tornou-se, a partir da segunda metade do século XIX, o principal produtor de alimentos da região. Na década de 1870, com a criação da Estrada de Ferro Leopoldina Railway, passou a intermediar tanto o café oriundo de Cantagalo em direção ao porto do Rio de Janeiro quanto os produtos da capital rumo à região do Paraíba Oriental. O município cresceu e surgiram novos estabelecimentos comerciais, hotéis, escolas - Colégio Anchieta e o Colégio das Dorothéas - e indústrias do ramo da construção civil, logo constituindo-se no centro urbano da região, onde os barões do café, como Antônio, o pai, e Bernardo Clemente Pinto, o filho, posteriormente, conde de Nova Friburgo, possuíam diversas propriedades e acabavam por influir decisivamente na política local. Foi Antonio, inclusive, quem recebeu do imperador Pedro II, em 1857, a concessão para a construção da estrada de ferro que ligaria o Rio de Janeiro a Cantagalo, inaugurada somente em 1873.

O fato é que, nos primeiros anos do século $\mathrm{XX}$, a região em torno de Nova Friburgo sofria o instante derradeiro de uma economia que se sustentara, até fins do século XIX, sobre o latifúndio escravista. Em contrapartida, assistia-se ao crescimento comercial e urbano de Friburgo, onde já havia uma indústria e comércio incipientes: diversas oficinas, como alfaiatarias e sapatarias, ligadas ao setor de vestuário, outras ligadas à fabricação de ferramentas, pequenas fábricas de alimentos como cerveja e café, além de um intenso comércio ambulante. A população crescia, e Nova Friburgo já se constituía, segundo o censo do Instituto Brasileiro de Geografia e Estatística (IBGE), na terceira cidade do centro-norte fluminense com 16.117 habitantes, atrás apenas de Cantagalo, com 29.856 habitantes, e de Itaocara, com 17.305. Durante os vinte anos seguintes, verificar-se-ia não só o aprofundamento dessa tendência, com o célere crescimento em cerca de $78 \%$ da população de Friburgo - em 1920, havia 28.651 habitantes, segundo censo do IBGE —, como também o segundo paralelo esvaziamento progressivo das cidades da periferia, que viviam a crise da economia cafeeira. Nova Friburgo, tendo se tornado sede de vários empreendimentos ligados ao comércio e à indústria, mesmo que ainda incipientes, ia se afirmando, 
então, como um pólo de atração para esses contingentes populacionais em fuga das então adversas condições de vida no campo.

Com o advento da República, veio a transformação da Vila de São João Batista de Nova Friburgo em município, e o seu desmembramento de Cantagalo, numa medida que fazia parte da estratégia de Deodoro da Fonseca para a consolidação de seu poder político nos estados. Essa mudança política não representou uma ruptura no quadro político local, que continuou sob a hegemonia dos setores ligados à grande propriedade, com destaque para os coronéis Galiano das Neves, pai e filho, e o médico Ernesto Brasílio, os quais ocuparam a presidência da câmara municipal e, por extensão, o governo da cidade, de 1890 a 1910, quando então surgia o movimento de oposição encabeçado por Galdino do Valle Filho.

Galdino, nascido a 24 de setembro de 1879 , filho de um proeminente homem político do município, o dr. Galdino Antonio do Valle, também médico, pertencente a uma familia de fazendeiros em Sapucaia, começou sua ação política partindo de uma situação vantajosa quanto ao capital pessoal de notoriedade acumulado: de um lado, por ser filho de renomado homem público e, de outro, por ser médico recém-formado, numa região, à época, carente de tais serviços. Sua atividade profissional já impulsionada pelo pai rendeu reconhecimento inicial por parte da população, o que facilitou sua projeção na vida política. Mas o que fez dele uma destacada liderança política, dando-lhe condições de forjar um novo e influente grupo político capaz de disputar e conquistar a hegemonia do poder local, foi o seu projeto de cidade, fundamentado em uma visão de mundo que pregava, acima de tudo, o advento do progresso e da civilização que somente a indústria seria capaz de trazer para o município.

Galdino, entusiasmado pelas teorias cientificistas que, na virada do século XIX para o XX, conformavam o pensamento hegemônico predominante na Europa, com reflexos no Brasil, representou na cidade os interesses de renovação social no sentido de aprofundar o processo de urbanização e de industrialização. Essas idéias evolucionistas com as quais, com certeza, Galdino entrara em contato na Faculdade de Medicina do Rio de Janeiro, onde fora colega de Azevedo Amaral e Carlos Chagas, não permitiam mais às mentes identificadas com os ideais de progresso e civilização tão caros à considerada necessária e urgente modernização da cidade conviver com os resquícios de uma sociedade em decadência, representada pelo que restava da economia cafeeira escravista. Era preciso, pois, desencadear a mobilização da sociedade friburguense, ou de sua parte interessada, no sentido da substituição do grupo político então dominante, formado por representantes dos fazendeiros de café. Galdino tornou-se o porta-vOz do projeto modernizador e progressista que, através das páginas do seu jornal A Paz, fundado em 1906, pregava a grande transformação da cidade, capaz de elevá-la ao 
plano da "civilização ocidental", rompendo em definitivo com o atraso e a decadência. Somente a instalação de indústrias em Nova Friburgo, patrocinando novos empregos e produzindo lucro e riqueza, poderia de fato promover a cidade à condição do progresso imaginado segundo os padrões da Europa, modelo a ser imitado conforme o ideal de mundo dominante à época.

O primeiro passo para o sucesso de sua estratégia foi, em 1909, a conquista, por 631 votos, de uma cadeira, para o triênio 1910-12, na Câmara de Vereadores de Nova Friburgo, onde se destacou, então, na oposição ao governo de Ernesto Brasílio. Também concorreu e foi eleito para a Assembléia Legislativa do estado, para o mesmo período legislativo, já que, à época, não havia incompatibilidade entre os cargos de vereador e deputado. Nesse período se travariam conflitos decisivos para a redefinição do jogo político da cidade.

\section{“Um bando de idéias novas" na virada do século}

Podemos inserir a visão de mundo abraçada pelo grupo de Galdino do Valle Filho na ideologia liberal, que, na verdade, está na raiz das idéias evolucionistas de tipo spenceriano e do darwinismo social, tão em voga no início do século XX. Segundo tais teorias, haveria uma seleção natural na sociedade, expressa na luta pela vida e na concorrência, a premiar os mais capazes e a deixar para trás os incompetentes. Liberalismo e evolucionismo caminhavam de mãos dadas no Brasil, desde a segunda metade do século XIX, através das propostas reformistas defendidas pelos abolicionistas e por aqueles que vinham pregando um regime baseado na indústria, na pequena e média propriedade e no trabalho assalariado, passo inicial para integrar o Brasil ao mundo civilizado.

\section{“Razão, ciência, progresso e liberalismo"}

"Era o drama do progresso, a palavra-chave da época: maciço, iluminado, seguro de si, satisfeito, mas acima de tudo inevitável." Assim Hobsbawm (1996, pp. 23, 21) caracteriza a segunda metade do século XIX, a "era da burguesia triunfante", em virtude do vertiginoso avanço da economia capitalista em escala mundial, do célere processo de industrialização que, partindo da Europa e dos Estados Unidos, invadia os outros continentes, com produtos industrializados, máquinas, estradas de ferro, empréstimos, novas tecnologias e muita violência. Violência física para garantir a exploração da mão-de-obra barata, e violência simbólica, com a qual se efetivava a conquista de corações e mentes 'primitivos' para a nova ordem social dominante no mundo ocidental. O capitalismo industrial, por meio de seus agentes sociais, consolidava a nova hegemonia que, a depender da vontade da confiante burguesia, deveria prevalecer no conjunto do planeta, através das "idéias 
e credos que pareciam legitimá-lo e ratificá-lo: na razão, ciência, progresso e liberalismo".

A ideologia do progresso e da ciência como panacéias para os males do mundo impunha-se, então, acompanhando o fortalecimento do poder burguês, constituído em torno de uma nova ética, pela qual não tinham mais efeito o poder e a influência derivados de privilégios de nascimento ou de status, como nos tempos do Antigo Regime. A nova moral estabelecia que o indivíduo, para se destacar na sociedade burguesa, tinha que ser um self-made man, que amealhava riqueza por seu próprio esforço, iniciativa e desprendimento. A vida em sociedade revelava-se através da competição entre os indivíduos, na qual a vitória ou mesmo a sobrevivência traduziam a capacidade moral e o mérito do vitorioso, numa "seleção natural" a colocar à margem os derrotados, vistos como seres "incapacitados", "degenerados", "preguiçosos". Assim se justificava a ordem desigual e perversa do capitalismo, para o que foram de grande valia as teorias de cunho cientificista, como o darwinismo social, o positivismo e o evolucionismo de tipo spenceriano, ideologias essas que, acima de tudo, tentavam enquadrar as relações sociais nos modelos das leis físicas, "naturais" e "invariáveis".

O habitus burguês incorporava o sentido de superioridade, o qual, segundo as teorias citadas, era o resultado de uma seleção natural, transmitida geneticamente e transformando todo membro da burguesia em um ser biologicamente superior à média dos mortais. Isso fazia do burguês não apenas um capitalista, ou seja, um possuidor de capital, um empresário em busca de lucro, um ser ativo por excelência, mas, ao mesmo tempo, um "senhor", um homem com o monopólio de comando, com inquestionável direito de dominar, seja em sua casa ou na empresa, tratando seus subordinados — mulher, filhos ou empregados - como inferiores.

O direito de propriedade, tão caro ao pensamento liberal, aparecia como indissociável ao direito de dominação, pois era necessário impedir quaisquer ameaças que pudessem surgir contra a propriedade, principalmente da parte dos trabalhadores, que deveriam se portar como "leais" e "satisfeitos", a exemplo das mulheres e filhos. Assim completa Hobsbawm (op. cit., pp. 340-1):

A burguesia dos penúltimos 25 anos do século XIX era esmagadoramente 'liberal'... num sentido ideológico. Acreditava no capitalismo, empresa privada competitiva, tecnologia, ciência e razão. Acreditava no progresso, numa certa forma de governo representativo, numa certa quantidade de liberdades e direitos civis, desde que compatíveis com a regra da lei e com o tipo de ordem que mantivesse os pobres no seu lugar.

Tais eram, portanto, as idéias que prevaleciam no universo cultural burguês, que tinha na Europa seu principal centro irradiador. O mundo 
ocidental devia enxergar na Europa o modelo de civilização a ser imitado e, para tal, a assimilação dos pontos de vista e teorias então em voga naquele continente era condição sine qua non. Essas idéias que passavam a ser hegemônicas no Brasil da virada do século XIX para o XX eram filtradas pela fração intelectual dominante, de acordo com as preocupações que a envolviam na tentativa de explicar e encontrar respostas objetivas que dessem conta dos problemas brasileiros. Não se tratava, pois, de mera imitação ou cópia das teses formuladas pelos europeus, mas uma escolha, entre as teorias disponíveis, daquelas idéias que, na ótica dos intelectuais, melhor correspondessem às necessidades internas brasileiras, dando conta de temas candentes à época, tais como a abolição do trabalho escravo e a mudança do regime político, de monarquia para república. Mas é inegável que o pensamento liberal burguês penetrava de forma intensa, passando a ser referência para novas atitudes e demandas políticas, a acompanhar as mudanças processadas no campo socioeconômico, a partir da efetiva incorporação de relações capitalistas de produção.

O "novo liberalismo", segundo expressão de Joaquim Nabuco para designar o movimento surgido nos estertores da monarquia, encabeçado por políticos, jornalistas, intelectuais, propunha reformas centradas na abolição do braço escravo e na mudança das regras eleitorais. O movimento reformista visava então romper o "atraso" do país em relação às nações mais "adiantadas", dentro de um programa que representaria um "meio-termo entre o regresso e a revolução" (Bosi, 1993, pp. 230, 237). A crise política, insuflada por "um bando de idéias novas", nas palavras de Sílvio Romero, acabaria por empurrar o país para a solução republicana. Travar-se-ia, então, uma batalha política entre aqueles que visavam substituir o modelo do velho império oligárquico e escravista. De um lado, o "positivismo ortodoxo", com Miguel Lemos, Teixeira Mendes e Benjamin Constant, abraçava o projeto de um Estado centralizador, racionalizador e, no limite, tutelar. De outro, o evolucionismo de tipo spenceriano, de um Sílvio Romero, por exemplo, "pendia para o liberalismo clássico e acreditava na sabedoria da seleção natural que, mediante processos de concorrência, premiaria os mais capazes".

Liberalismo e autoritarismo, "no frigir dos ovos", iriam conviver durante vários anos com a República. A Constituição federalista de 1891 adequava-se perfeitamente aos interesses dos grupos dominantes agrário-exportadores, garantindo a total liberdade para a gestão de seus negócios. O liberalismo, aqui, combinava-se a uma concepção mercantil da vida social. Também os donos de indústrias viam-se livres de quaisquer obrigações para com seus empregados, o inverso não tendo correspondência, como só podia ser com uma legislação que garantia total liberdade à atividade empresarial e tratava a reivindicação operária como caso de polícia, exigindo aí a pronta ação coercitiva do Estado. 
O autoritarismo político convivia, então, com um arcabouço jurídico liberal, copiado das constituições liberais européias e norte-americana, que mascarava a realidade social excludente, no momento de implementação de um mercado de trabalho capitalista após a abolição do trabalho escravo. Uma das preocupações centrais da classe dominante brasileira, composta principalmente pelos setores de grandes proprietários de terras, foi a de manter o controle social, antes exercido dentro das fazendas, e, naquele instante, mais difícil de ser praticado nas cidades. Houve a opção clara pela tentativa de controle social absoluto, através da "limpeza", da "varredura" étnica e cultural, com a repressão sendo exercida centralmente sobre o negro e o mestiço. A administração pública convivia, portanto, com leis de inspiração liberal e práticas repressivas de controle social, num momento em que a idéia de nação estava sendo construída e se confundia ainda com o aparato do Estado.

Sem sombra de dúvida, esse conjunto de idéias, acompanhando as transformações socioeconômicas que sacudiam as velhas estruturas do Brasil oligárquico e que foram responsáveis pela queda da já cambaleante monarquia e sua substituição pela República, influenciou os jovens homens políticos da época, como um Galdino do Valle Filho. O discurso de uma fração da classe dominante de Friburgo incorporavase, então, a um projeto modernizante existente em âmbito nacional, sob a hegemonia dos grandes proprietários paulistas, mas que, conforme veremos adiante, em termos do Rio de Janeiro também tinha seus representantes, como, por exemplo, Alberto Torres. Tanto o discurso nacional quanto o local enalteceriam a mão-de-obra imigrante européia como capaz de forjar uma nova nacionalidade, uma "nova raça", que apagaria em definitivo os vestígios do atraso causado pela escravidão negra e traria o progresso.

Os friburguenses lamentar-se-iam de que o restante do país não tivesse tido a oportunidade de adotar o projeto posto em prática no século XIX em Nova Friburgo, quando da implantação da colônia suíça por d. João VI, projeto esse fundador de uma sociedade "próspera" e "civilizada", pois baseada no trabalho do europeu livre e na pequena propriedade. Tal aspecto da ideologia elaborada pelo grupo de Galdino com respeito às origens da cidade de Friburgo será focalizado mais adiante, quando tentaremos analisar o mito da Suíça brasileira. Cabe adiantar que a construção da ordem liberal em Friburgo não abriria mão, a exemplo do processo que ocorria em âmbito nacional, do controle social a ser exercido sobre a classe trabalhadora, através tanto da repressão policial quanto de uma política voltada para a propaganda ideológica, para o que o discurso com referência aos suíços seria providencial, no sentido de realçar os traços "civilizados" do povo helvético, como o "amor ao trabalho", a "disciplina", o "espírito de iniciativa" etc. O chamamento à ordem esteve sempre acompanhando a afirmação do progresso, como asseverava a cartilha positivista, cujos 
preceitos seriam constantemente citados em editoriais e artigos dos jornais que circulavam na cidade.

\section{Galdino e a industrialização de Nova Friburgo}

A fim de concretizar sua estratégia política e garantir a instalação de indústrias em Nova Friburgo, Galdino liderou, por meio de seu jornal A Paz, campanha em prol da entrega ao empresário alemão Julius Arp da concessão para a exploração de energia elétrica no município, condição essa exigida pelo empresário para instalar a Fábrica de Rendas em Friburgo. Travou-se uma verdadeira guerra na cidade, com manifestações públicas que redundaram, em 17 de maio de 1911, na "Noite do Quebra-Lampiões" e em quebra-quebra na Câmara Municipal. O Legislativo Municipal era contrário às pretensões de Galdino, pois a concessão da energia elétrica, de sua competência, havia sido dada, em 1906, ao coronel Antônio Fernandes da Costa, ligado à facção política dominante. Além disso, a Câmara era presidida pelo coronel Galiano Emílio das Neves Júnior, representante do grupo dos fazendeiros de café, contra o qual lutava Galdino. Ao negar a concessão da energia elétrica ao Grupo Arp, a Câmara provocou o descontentamento de parte da população, que já havia sido conquistada pela perspectiva de desenvolvimento e de novos empregos que a indústria daria à cidade. Os velhos lampiões da iluminação pública foram quebrados e, em seguida, o prédio do Legislativo foi apedrejado e invadido por uma multidão de quinhentas pessoas.

A estratégia de Galdino terminou por se fazer vitoriosa, com a Câmara pressionada pela ação popular, sendo obrigada a rever a antiga concessão e a passá-la aos alemães. Logo, durante as décadas de 1910 e 1920, Friburgo via instaladas as primeiras fábricas têxteis: Fábrica de Rendas Arp, Markeis Sinjen \& Cia., em 1911; Fábrica Ypu, Maximilian Falck \& Cia., em 1912; Fábrica Filó S.A., principais acionistas: Gustav Siems e seu filho, Ernst Otto Siems, em 1925, e outras, além da criação da Companhia de Eletricidade, com capital privado do grupo Arp, o qual, por sinal, teria ações em todas essas fábricas, constituindo-se no principal representante dos capitais alemães em Friburgo. Esse conjunto de embates políticos e a compreensão de que o processo de urbanização e industrialização de Friburgo fez parte de toda uma luta mais ampla pela hegemonia do poder local foram muito bem trabalhados pelo prof. João Raimundo de Araújo, em sua dissertação de mestrado, que ainda nos oferece um detalhado painel com dados estatísticos e preciosa documentação sobre a instalação das primeiras indústrias no município.

Galdino do Valle Filho chegava à frente do poder municipal no ano de 1913 sendo eleito presidente da Câmara de Vereadores, cargo esse com que acumulava também as funções de prefeito. Higiene e saúde pública foram um capítulo especial de seu governo. No ataque às doenças infecciosas, como o tifo, a tuberculose e o alastrim, enfrentou 
o problema das águas, preservando a zona da represa de abastecimento e adotando campanha de vacinação, além de isolar os doentes em prédio próprio (o Lazareto). Foi criado ainda o Serviço de Obras, que reconstruiu o leito das ruas e criou novos jardins públicos. O grupo de Galdino, nessa hora, buscando consolidar-se como dominante, iria representar, daí por diante, em primeiro lugar, os interesses dos empresários donos das indústrias, ao capitanear o projeto de construção da cidade nos moldes modernizantes da época, que contribuía sobremaneira para a afirmação de uma mentalidade liberal e enfatizava o progresso econômico trazido pelas indústrias.

O jornal $A$ Paz, no período, seria o principal veículo a divulgar o pensamento do grupo, a exemplo do artigo publicado na edição de 28 de março de 1915, sob o título 'Friburgo industrial', que traduzia de maneira precisa o sentimento triunfante na vitoriosa estratégia industrialista adotada no município, a começar por fazer apologia ao trabalho dos imigrantes - "ninguém vem viver na América para se divertir e sim para trabalhar" - , representados como uma humanidade ativa, em contraposição ao trabalhador nacional, mostrado como passivo e parasita. Nas fábricas de passamanaria e de rendas, mantidas, segundo o artigo, por inteligentes e esforçados elementos alemães, os ruídos das máquinas, que entoariam uma canção em honra ao trabalho, pareciam combinar perfeitamente com a paisagem das montanhas e com o clima evocativos da Europa, onde "os dínamos vão transformando a Suíça em nação industrial, e as solidões alpestres do Tirol se cobrem de manufaturas".

O artigo ilustra um quadro romântico do progresso trazido pelos alemães - instalação da iluminação elétrica, de uma passamanaria (M. Falck \& Cia.) e de uma fábrica de rendas (Arp), que, tendo começado com sessenta, contaria então com 150 teares em atividade constante. É interessante notar-se o destaque, no texto, à iniciativa individual. Apresentada como a vara mágica gerada pela ambição e pelo interesse que impunham leis até à natureza, retrata com fidelidade o espírito liberal burguês do grupo agora dominante, que não se importava em ufanar-se da empresa estrangeira, numa atitude pragmática: "afaguêmola, mesmo alienígena, ... porque ... os capitais e os dotes não têm pátria”. Dessa forma, cantando loas à indústria e ao trabalho organizado nos moldes capitalistas, o grupo de Galdino ia se afirmando, naqueles anos, como hegemônico no município, não sem enfrentar novas adversidades políticas, causadas, principalmente, por suas alianças em âmbito estadual e nacional.

Além de, por várias outras vezes, ter assumido a presidência da Câmara Municipal, Galdino foi eleito deputado estadual, deputado federal e prefeito, após a criação deste cargo em 1916 e o respectivo estabelecimento de eleições em 1922. Marieta de Moraes Ferreira destaca as articulações políticas estaduais em que se situava Galdino, desde 1914 na oposição ao líder político Nilo Peçanha. Este comandara o 
poder estadual dos primeiros anos do século XX até 1923, quando houve a intervenção federal no estado em represália à sua candidatura de oposição à presidência da República, em 1922, no movimento conhecido como "reação republicana".

Durante os vários momentos do conflito entre Galdino do Valle Filho e o grupo nilista, destacou-se o instante da criação de novas prefeituras no estado, em 1916, com a clara intenção de esvaziar as funções administrativas das câmaras municipais em que houvesse o domínio de grupos não submetidos ao controle do nilismo, como era o caso de Nova Friburgo.

Nesse ano, já havia se travado intensa batalha jurídica em torno da eleição para a Câmara de Vereadores conquistada pelo grupo de Galdino, o que lhe garantiria a continuidade à frente do poder político municipal. Nilo Peçanha interveio no processo e conseguiu, momentaneamente, mudar o resultado junto ao Tribunal de Apelação estadual, nomeando, então, um interventor. Mais adiante, Galdino conseguiu reverter o quadro junto ao Supremo Tribunal Federal (STF), ao que Nilo respondeu com a criação da Prefeitura de Nova Friburgo, em 19 de agosto de 1916 (Ferreira, 1989, pp. 211, 229).

Desse ano até 1922, quando seriam conquistadas as eleições diretas para o cargo de prefeito, o Executivo Municipal ficaria em mãos de Ś1vio de Fontoura Rangel, deputado estadual com base eleitoral no município de Vassouras, nomeado interventor em Friburgo por Nilo Peçanha. Galdino passou, então, a liderar campanha pela autonomia municipal, através de eleições diretas para o cargo de prefeito. Outro momento de importante conflito ocorreu em 1919, quando Galdino Filho conseguiu eleger a totalidade dos vereadores friburguenses, e, em represália, Sîlvio Rangel entrou com recurso no Tribunal de Relação, obtendo a anulação do resultado e mantendo o domínio do poder local, o que teria provocado inúmeros choques armados.

Algumas importantes divergências em relação aos projetos econômicos distintos para o estado também envolviam as disputas travadas pelos grupos em questão. Essas diferenças foram postas com maior nitidez durante a campanha eleitoral de 1922 para a presidência do estado, quando ainda era hegemônica a posição de Nilo Peçanha, o qual lançou candidato Raul Fernandes, estando na outra chapa Feliciano Sodré, indicado pelas Forças Reunidas da Oposição Fluminense. A corrente niilista apresentava um programa econômico eminentemente direcionado para um desenvolvimento agrarista, em que a policultura seria a pedra angular, e o grupo de Sodré, no qual se inscrevia Galdino do Valle Filho, propunha o estabelecimento de uma alternativa econômica com a criação de atividades voltadas para um desenvolvimento industrial e urbano.

$\mathrm{Na}$ verdade, poucas foram as propostas de ordem reformista no estado do Rio que se dedicaram a abordar projetos para além dos limites da questão agrária, como bem já analisou Marieta de Moraes. 
As proposições reformistas aglutinaram-se em torno de uma série de idéias que circulavam mais intensamente na passagem do século XIX para o XX, difundidas pela Sociedade Nacional de Agricultura, entidade na qual articulavam-se os proprietários rurais interessados em discutir propostas alternativas, no sentido de uma regeneração da agricultura por meio da diversificação da produção. Essas idéias surgiam na tentativa de solucionar a crise provocada, segundo os proprietários, pela abolição da escravatura e pela ausência de mão-de-obra capacitada a integrar um projeto capitalista no campo. Alberto Torres destacava-se, naquele momento, como intelectual e político com idéias de renovação econômica, apontando os males causados pelo latifúndio e pela monocultura de exportação, propondo, como alternativa, a ampla difusão e apoio à pequena propriedade, bem como a diversificação da produção agrícola, voltando-se prioritariamente para o mercado interno (Ferreira, 1994, p. 59).

Tanto entre os adeptos da chapa de Nilo, quanto entre os da oposição, essas idéias circulavam, com os dois grupos querendo se apresentar como defensores de uma proposta 'moderna' para a economia do estado, sendo que somente o grupo no qual se inscrevia Galdino apontava claramente no sentido de uma alternativa industrializante. Não podemos deixar de relacionar à peculiar história de Nova Friburgo essa posição do grupo galdinista de uma economia justamente voltada para o mercado interno, em que a pequena propriedade era sua base fundamental. Tal posição pode ter favorecido a rápida urbanização e precoce industrialização de Nova Friburgo nas primeiras décadas do século XX, ao passo que a grande maioria dos outros municípios fluminenses continuava a se dedicar primordialmente à grande lavoura monocultora de exportação. Tais propostas, no entanto, esbarraram em uma série de obstáculos, sobretudo na posição dos grandes proprietários de terra, produtores de café ou açúcar, pouco interessados na diversificação da agricultura, menos ainda em mudanças no caráter da propriedade. A mentalidade dos proprietários fluminenses prendiase a uma tradição em que o prestígio social era assegurado pela posse da terra e da grande lavoura, sendo que a produção de alimentos para o mercado interno era vista como atividade menor, além de pouco lucrativa.

Conquistadas as eleições para o Executivo Municipal no ano de 1922, Galdino se elegia prefeito e era também eleito para o cargo de deputado federal. Dessa data até a revolução de 1930, o grupo de Galdino do Valle Filho comandaria o poder político em Nova Friburgo, representando, em primeiro lugar, os interesses dos grandes empresários e comerciantes locais, que, desde 1917, estavam organizados na Associação Comercial de Nova Friburgo e influíam nas decisões tomadas pela prefeitura. O posicionamento do grupo de Galdino ficava explícito em vários artigos publicados no jornal $A$ Paz, porta-voz da corrente liberal, ao assumir a defesa dos empresários, por ocasião dos movimentos 
de luta contra os baixos salários ou por melhores condições de trabalho, organizados pelos operários das fábricas.

O grupo conseguiria mais um ponto a favor de seu projeto industrializante no ano de 1925, quando se instalou em Friburgo a Fábrica Filó S.A., produtora de bordados, transferida da Alemanha, em virtude da crise econômica do pós-guerra, que obrigava seu proprietário, Gustav Siems, a buscar condições mais favoráveis aos seus negócios. A indústria têxtil, no Brasil, à época, atraía investimentos estrangeiros em virtude dos baixos impostos e da mão-de-obra barata, que incluía muitas mulheres e crianças, além de trabalhadores oriundos do campo. Nova Friburgo multiplicaria o número de empresas instaladas, tanto no perímetro urbano quanto na área rural, pulando das 243 existentes em 1921 para 354 em 1927. Tanto é que, por causa desse crescimento, a usina hidrelétrica, construída em 1911, com $300 \mathrm{~kW}$ de força, já não comportaria a demanda em 1925. A concessionária, então, conseguiria aprovar proposta para construir nova usina, com $1.800 \mathrm{~kW}$, além de obter da Câmara Municipal outras concessões, tais como o adiamento da reversibilidade para o município da antiga usina e a não reversibilidade da nova, que ficaria pronta em 1925, quando fora criada para geri-la a Companhia de Eletricidade de Nova Friburgo (CENF) (Corrêa, 1985, p. 96).

Ao saber tirar proveito político do processo de industrialização em Friburgo, nas décadas de 1910 e 1920, e capitaneando o projeto de construção de cidade nos moldes modernizantes da época, essa facção política abriu caminho para a formação de uma mentalidade liberal, dando ênfase ao progresso econômico por meio da instalação das indústrias. No ideal de cidade construído pelo grupo, seriam realçados os elementos particulares da formação histórica friburguense como constituintes de um modelo sui generis de município no Brasil, uma ilha de 'civilização' em meio ao 'atraso' causado pelo latifúndio e pelo trabalho escravo.

Na elaboração do modelo de cidade ideal que deveria ser Nova Friburgo, que se tornou hegemônico ao fazer parte do processo mais amplo de afirmação da nova ordem burguesa no início do século XX, destacou-se toda a construção ideológica definidora de uma identidade cultural que correspondesse ao projeto modernizante. Foi-se buscar no passado de Friburgo, relacionando-o à colonização suíça encaminhada por d. João VI em 1818, a origem de um burgo 'europeu', como sinônimo de cidade 'civilizada' e 'progressista'. A imagem de moderna cidade do início do século XX, inserida no processo de industrialização, casava-se perfeitamente com um passado original de região colonizada por europeus, onde a pequena propriedade trabalhada pelos imigrantes brancos e 'civilizados' não teria permitido a presença do latifúndio e da mão-de-obra escrava e negra, símbolos de um país decadente, em vias de ser ultrapassado e esquecido. 


\section{O mito da Suíça brasileira}

A construção idealizada do passado de Friburgo, integrada, portanto, ao projeto hegemônico liberal e capitalista do início do século XX, seria cuidadosamente elaborada pelas autoridades e pela imprensa locais, quando das comemorações do centenário de Nova Friburgo, em 1918. Nessa oportunidade, foram criados os símbolos da Súça brasileira, como o hino e a bandeira de Nova Friburgo, além de se realizar uma sessão solene na Câmara Municipal, no dia 19 de maio, com palestras proferidas por personalidades de fora da cidade, tais como a de um representante do Instituto Histórico-Geográfico Fluminense, Luiz Palmier, e a do jornalista Agenor de Roure, "filho ilustre de Friburgo", que ocupava o cargo de redator de atas na Câmara dos Deputados, no Rio de Janeiro. Essas autoridades - vários representantes do governo do estado, de câmaras dos municípios vizinhos e um ministro da Suíça - vinham, com seu peso intelectual e institucional, dar legitimidade ao projeto que se desejava construir.

Destacava-se a presença de Agenor de Roure, de quem se pode dizer ter sido um dos grandes ideólogos, ou mesmo, o grande ideólogo do mito da Suíça brasileira. Agenor de Roure, que, em 1921, viria a ser o secretário particular do presidente da República, Epitácio Pessoa, já em 1915 apresentara às autoridades friburguenses a proposta de comemoração do centenário de Nova Friburgo, firmando a data de 16 de maio de 1918 para o evento, quando faria cem anos a assinatura do decreto de d. João VI confirmando o projeto de colonização. A escolha de tal data, mais tarde, seria motivo de polêmica entre escritores e historiadores em Friburgo, pois muitos argumentariam que faria mais sentido comemorar o aniversário do município tomando por base o ano de 1820, quando os suíços chegaram efetivamente à fazenda do Morro Queimado e assentaram simbolicamente a fundação da Vila de Nova Friburgo.

Galdino do Valle Filho abraçaria integralmente a idéia do centenário e defenderia a imediata mobilização dos friburguenses no sentido de sua organização, conclamando, em particular, as futuras autoridades municipais a fazerem das comemorações a sua preocupação máxima. No entanto, não fazia parte dos planos de Galdino, que, em 1918, seu adversário político, Sílvio Rangel, representante do grupo nilista em Friburgo, viesse a ocupar o governo municipal. De qualquer forma, estando Galdino, naquele ano de 1915, à frente do Executivo por ser o presidente da Câmara, seu nome, entre os homens políticos do município, ficaria marcado como um dos principais idealizadores do projeto do centenário.

\section{Agenor de Roure e o plano de d. João VI}

Importa realçar, então, a tese de Agenor de Roure sobre a fundação de Nova Friburgo, a qual se ajustaria perfeitamente ao projeto 
modernizador de Galdino do Valle Filho e de seu grupo. Segundo Agenor de Roure, a criação de Friburgo teria feito parte de uma "nobre e elevada preocupação" de d. João VI em dar uma nova orientação ao povoamento do país:

A fundação da colônia suíça do Morro Queimado tem uma alta significação na história do povoamento do Brasil. Ela representa ... o início da execução de um plano inteligente de d. João VI.

Mudada a Corte de Lisboa para a Bahia e depois para o Rio de Janeiro, o rei teve ocasião de verificar o erro dos governantes portugueses no povoamento da terra de Santa Cruz. ...

Tivesse ele podido levar por diante o seu plano e nós não estaríamos sofrendo as conseqüências da nefasta influência que o trabalho escravo exerceu sobre a nossa formação étnica e sobre a nossa organização econômica. Dezenas, centenas mesmo de núcleos de europeus industriosos, espalhados pelo país, teriam diminuído aquela influência, teriam preparado o país para a transformação do trabalho escravo em trabalho livre.

${ }^{1}$ A conferência de Agenor de Roure, proferida a 19 de maio de 1918 , foi transcrita, em forma de artigo, na Revista do Instituto Histórico e Geográfico Brasileiro (1918, tomo 83 , pp. 243,266$)$, sob o título 'O centenário de Nova Friburgo'.
... Assim a fundação da Colônia Suíça do Morro Queimado, cujo centenário comemoramos hoje, não é um fato histórico interessando apenas ao nosso município, porque traduz o início de um belo plano de organização de trabalho livre e adiantado em contraposição ao trabalho escravo, em todo o Brasil. Interrompida a execução desse plano, o trabalho escravo venceu, entravando o progresso e o desenvolvimento econômico do país e invadindo as próprias colônias organizadas exclusivamente com homens livres (Soares, 1952, pp. 122, 123).

A sua palestra na Câmara Municipal de Nova Friburgo ${ }^{1}$ apresentava a fundação da Colônia do Morro Queimado como parte de um amplo projeto de d. João VI, com vistas a corrigir a formação étnica brasileira, que teria sido perturbada e viciada pelo sistema de povoamento adotado até então. À "influência nefasta" da escravidão, responsável pela caça aos indígenas e pelo roubo de negros na África, teria vindo somar-se negativamente o processo de transferência, para o Brasil, de criminosos e degenerados da Europa, transformando a Colônia em depósito da "escória" européia, segundo ele, arrebanhada nos "antros da vadiagem" das grandes cidades marítimas, processo esse que teria continuado após a independência, com a imigração subvencionada.

A intenção de d. João VI teria sido a de, introduzindo colonos brancos e livres, apontados como homens capazes, industriais e agricultores, promover o rápido progresso do país e, com o tempo, forjar uma nova nacionalidade, com caracteres de uma "raça perfeitamente definida". Através de "cruzamentos" étnicos, a partir da instalação de colônias suíças, alemães, irlandesas, açorianas, promover- 
se-ia a substituição dos núcleos de povoamento iniciais, formados por "homens sem vontade, sem liberdade e sem instrução", incapazes de gerar uma "alma nobre", de "ter iniciativa, lutar e vencer, progredindo e civilizando-se". Tão logo a nacionalidade estivesse formada, com os novos traços culturais e étnicos, as linhas principais desse novo caráter seriam perpetuadas por meio da hereditariedade, conservadas "sem mais cruzamentos" (Roure, 1918a, pp. 234-66).

Percebe-se aí a intenção de ligar ao "plano de d. João VI" uma política de branqueamento da população brasileira. Somente a imigração européia teria podido levar o Brasil à condição de país civilizado, apagando a indesejável marca da cor negra, além de propiciar o seu desenvolvimento econômico, graças à "laboriosa" mão-de-obra dos europeus, mais "capaz" e "inteligente". A ideologia do branqueamento do povo brasileiro era uma das propostas pertencentes àquele "bando de idéias novas", hegemônicas em fins do século XIX e início do século $\mathrm{XX}$, a que nos referimos anteriormente.

Conforme nos indica Renato Ortiz, as teorias raciais formuladas por autores como Sílvio Romero, Nina Rodrigues e Euclides da Cunha trabalhavam dentro da perspectiva evolucionista desenvolvida na Europa pelo positivismo comtiano, o darwinismo social e o spencerianismo. A história brasileira era apreendida em termos deterministas, com o clima e a raça servindo como aspectos definidores de seu "atraso". Começava a ser elaborado o "mito das três raças", que atribuía ao elemento branco uma posição de superioridade na constituição da população brasileira, ao passo que o negro e o índio eram apresentados como entraves ao processo civilizatório. Assim, aponta Ortiz (1985, p. 21):

O mestiço, enquanto produto do cruzamento entre raças desiguais, encerra, para os autores da época, os defeitos e taras transmitidos pela herança biológica. A apatia, a imprevidência, o desequilíbrio moral e intelectual, a inconsistência seriam dessa forma qualidades naturais do elemento brasileiro ... O ideal nacional é na verdade uma utopia a ser realizada no futuro, ou seja, no processo de branqueamento da sociedade brasileira. É na cadeia da evolução social que poderão ser eliminados os estigmas das 'raças inferiores', o que politicamente coloca a construção de um Estado nacional como meta e não como realidade presente.

Fica evidente que tais idéias, hegemônicas no Brasil na virada do século XIX para o XX, embasavam ideologicamente a interpretação histórica elaborada por Agenor de Roure. A questão da formação étnica brasileira constituía-se em preocupação central tanto para Agenor de Roure, quanto para a maioria dos intelectuais do período, uma vez que o que estava em causa era a própria concepção de nação brasileira. Dentro desse campo, surgiam, com igual força, temas ligados ao fator mão-de-obra, tais como a abolição, o aproveitamento do escravo como 
assalariado e a imigração européia. O intelectual friburguense já havia abordado o tema da abolição em palestra proferida na Sala das Sessões do IHGB, no dia 14 de maio de 1918. Agenor de Roure (1918b, p. 317), exaltando a promulgação da Lei Áurea, contrapunha-se àqueles que somente viram no fim da escravidão a desorganização do trabalho, pois, para ele, não havia trabalho organizado com a escravidão. Atacava os "vícios de origem" da colonização brasileira, responsáveis por uma herança nefasta, que obstaculizava o progresso econômico no país, apontando a alternativa que, se adotada, teria conduzido a uma outra realidade social:

\begin{abstract}
A fundação da pátria brasileira teria sido mais rápida e assentaria desde logo em bases sólidas, se em vez da doação de capitanias a felizes protegidos do trono, houvesse Portugal alicerçado a construção econômica da colônia no trabalho livre, na fácil conquista de lotes de terras, na entrada de colonos estrangeiros, que para aqui viessem e se instalassem livremente como nos Estados Unidos, constituindo seus lares como núcleos de uma pátria futura...
\end{abstract}

A conclusão a que chegava Agenor de Roure, tanto na palestra dada no instituto quanto na conferência proferida em Friburgo, era a de que, se d. João VI não tivesse sido obrigado a retornar a Portugal, seu plano, iniciado através de colônias de povoamento no Sul e em Nova Friburgo, teria sido adotado em todo país, mudando por completo os rumos da prejudicial colonização de origem, calcada no latifúndio e no trabalho escravo. O exemplo exaltado era o dos Estados Unidos da América, cujo processo de povoamento teria constituído, em tempo relativamente curto, uma "raça forte", transformando aquele país em uma potência econômica. O conferencista omitia o fato de que também nos Estados Unidos havia se desenvolvido o sistema de plantation, baseado na grande propriedade escravista e na monocultura de exportação.

Importa perceber que a sua interpretação acerca do plano de d. João VI inscrevia-se na perspectiva liberal burguesa do início do século $\mathrm{XX}$, a propagar idéias alternativas no campo da economia, a exemplo da defesa da diversificação na produção agrícola, estimulando a pequena propriedade e o trabalho assalariado do imigrante europeu, conforme vimos anteriormente. Também fazia parte desse ideário a promoção do progresso através da industrialização e do fomento do livre comércio. Não foi à toa que Agenor de Roure, em sua palestra, apresentou d. João VI como um "rei liberal", por ter aberto os portos brasileiros ao comércio das "nações amigas", pondo fim ao monopólio da metrópole sobre a colônia. O "plano de d. João VI", na verdade, foi a maneira pela qual Agenor de Roure, um intelectual orgânico do liberalismo no início do século XX, fez a defesa de um projeto de nação brasileira, nos moldes liberais burgueses, utilizando-se de pretensos fundamentos históricos, 
para ele inteiramente válidos, e que mais funcionavam como capital simbólico a ilustrar as idéias em torno das quais erigia o seu projeto de Brasil.

No momento das comemorações pelo centenário de Friburgo, portanto, estavam sendo criadas as tradições que passariam, anos mais adiante, a fazer parte do calendário oficial da cidade de Nova Friburgo. Essas "tradições inventadas", para utilizar a expressão de Eric Hobsbawm, passando a fazer parte do imaginário social criado pelas classes dominantes friburguenses, transformadas em ideologia, viriam a ser amplamente difundidas e incorporadas pela maioria da população friburguense. Isso porque a tradição inventada estabelece a ligação da comunidade a um passado histórico apropriado, que não pode ser totalmente artificial, pois há que permitir aos agentes identificarem-se como elos de continuidade a um processo histórico original, naquele momento apontado como o da gênese do grupo social. Como dizem Hobsbawm e Ranger (1984, p. 21), "toda tradição inventada, na medida do possível, utiliza a história como legitimadora das ações e como cimento da coesão grupal".

Um outro fator, além do étnico, era utilizado nos argumentos que ajudariam a consolidar o mito da Suíça brasileira: o clima da região serrana fluminense. A comparação com a Europa tornava-se inevitável e permitia que Galdino do Valle Filho empunhasse a bandeira a favor da cultura do trigo, que, segundo ele, não era praticada em extensão digna de nota no Brasil, a não ser no Rio Grande do Sul. Defendia que, em decorrência da Primeira Guerra Mundial, era urgente que os lavradores fluminenses, mormente os de Nova Friburgo, cujo clima seria igual ao da Europa, passassem a se dedicar à produção do cereal, para suprir as necessidades internas, antes abastecidas através da importação. Em editorial do jornal $A$ Paz, edição de 10 de julho de 1915, afirmava: “... base principal da alimentação do homem civilizado e indício tão sabido do seu progresso que, já o disse alguém, pelo cultivo do trigo, se pode determinar na carta geográfica a marcha triunfal da civilização pelo mundo".

Mais uma vez, a ideologia do progresso se fazia presente, indicando que Nova Friburgo era uma das poucas regiões abençoadas no Brasil, por estar incluída no rol dos "civilizados", quanto mais não fosse em virtude de seu clima frio, que possibilitava o fomento de atividades características do mundo desenvolvido.

O enaltecimento ao trabalho livre e ao espírito de iniciativa individual, traços característicos dos "avançados" povos da Europa e dos Estados Unidos, imprescindíveis para integrar o país ao desenvolvimento capitalista, eram inerentes ao discurso desse grupo de intelectuais e políticos burgueses, no qual incluímos as figuras de Agenor de Roure e Galdino do Valle Filho. Por isso o mito criado em torno da Suíça brasileira casava-se tão perfeitamente com o projeto mais geral de uma política econômica que trilhasse o caminho da 
2 Também é rico na análise da presença de escravos em Friburgo o trabalho baseado em estudos sobre o código de posturas de 1848 , Inquérito sobre escravidão em Nova Friburgo, de Jorge Miguel Mayer e Edson de Castro Lisboa, à disposição no Departamento PróMemória da Prefeitura Municipal de Nova Friburgo (mimeo.). industrialização e da urbanização, ao mesmo tempo que incentivasse a produção agrícola diversificada, com estímulo à pequena propriedade e ao trabalho livre.

A Nova Friburgo industrializada e "progressista" do início do século XX não poderia, para a facção política liberal, ser identificada a um passado de escravidão e pobreza. Por isso sua fundação era contada como um feito de heróicos desbravadores, a cumprirem o destino de transformar as adversidades encontradas em sucesso, promovendo o progresso e erigindo uma cidade "paradisíaca", para o que teria sido essencial a formação étnica e cultural daqueles indivíduos. Vários aspectos negativos presentes na história do município — a verdadeira desventura que representou a chegada dos suíços em 1820, a contribuição dos negros e a presença da escravidão — seriam esquecidos pelos homens políticos responsáveis pela elaboração da sua identidade. O passado, manipulado em função dos interesses do presente, não seria mostrado em sua totalidade, promovendo-se a "ocultação dos aspectos não-oficiais do acontecimento escolhido, notadamente, das provações e lutas dos setores populares" (Chesneaux, 1995, p. 31).

Mesmo não tendo igual peso que os municípios vizinhos, cujas economias eram cafeeiras e escravistas, a exemplo de Cantagalo, a escravidão negra fez parte da formação histórica de Nova Friburgo (Louzada, 1991). ${ }^{2}$ O negro escravo teve papel importante seja no campo (vários colonos suíços e alemães eram proprietários de escravos ), seja na zona urbana, através de documentação que comprova a existência de considerável população de escravos em Friburgo. O censo demográfico de 1872 (fonte: IBGE) indicava a existência de 897 escravos em meio à população de 6.303 habitantes da Vila de São João Batista de Nova Friburgo, o que perfazia cerca de 14\% da população. Nas paróquias, onde se fixava a grande maioria da população — $70 \%$ do total do município -, suplantando em muito a área urbana, essa percentagem era bem maior, já que representavam regiões dedicadas à lavoura do café. Em São José do Ribeirão, atual município de Bom Jardim, os escravos equivaliam a 39\% da população da paróquia 3.072 contra 7.962 - enquanto em Nossa Senhora da Conceição do Paquequer, atual município de Sumidouro, representavam 54\% dos habitantes do local - 2.167 escravos em meio a 4.015 moradores (Araújo, 1992, pp. 61, 62).

Há também que se desmistificar a visão idílica que envolve a vinda dos imigrantes europeus, a começar pelo fato de boa parte dos imigrantes ser de indivíduos considerados "indesejáveis" na Suíça, obrigados a fazerem parte de uma "operação limpeza" ou de escaparem da fome e da miséria que grassavam em várias regiões do país. A trágica viagem, durante a qual morreu um em cada seis emigrados, e as condições adversas encontradas na fazenda do Morro Queimado, cujas terras distribuídas eram de qualidade desigual, muitas das quais incultiváveis e localizadas em encostas e picos escarpados, completam o quadro de 
uma situação nem um pouco idílica. Descritos como valentes desbravadores e "colonizadores", na verdade, os suíços enfrentaram imensas dificuldades para se estabelecer na colônia, não encontrando a mínima infra-estrutura ou os recursos prometidos pelo governo de $\mathrm{d}$. João VI. Acalentando o sonho do enriquecimento rápido e fácil, os imigrantes depararam-se com outra realidade: pequenos lotes de terra e vias de escoamento dos possíveis produtos excedentes em péssimas condições.

Em cerca de dez anos, após a fase inicial, quando os colonos foram mantidos pelos subsídios enviados pela Corte portuguesa instalada no Rio de Janeiro, a população de 1.631 suíços instalados caiu para cerca de sseiscentos. Os mil restantes emigraram em busca de melhores condições no Rio, em Macaé, e, principalmente, em Cantagalo, onde o café proporcionava o sonho de riqueza imediata. Ficaram em Nova Friburgo aqueles que conseguiram vencer as adversidades na lavoura, dedicando-se à agricultura de subsistência. Além disso, já se vinha verificando na região uma progressiva ocupação luso-brasileira, cujos integrantes teriam maior participação na vida econômica local e assumiriam de fato a direção político-administrativa da Vila. Pode-se arriscar, segundo historiadores especializados no tema em questão, que os suíços acabariam "marginalizados", casando-se entre si e constituindo pequenos núcleos concentrados nas imediações da Vila (Mayer e Pedro, s. d.).

A esperança dos emigrados, expressa em seu canto de partida da Suíça, segundo o qual buscavam a "vantagem de ser burgueses para sempre" (Nicoulin, 1996, p. 136), não encontrou o terreno desejado, mas sua imagem ilusória inicial acabou por ser resgatada, um século mais tarde, pelos homens políticos interessados em constituir uma identidade cultural para a cidade, dentro de uma nova realidade social vivenciada. Já no final do século XIX, o retrato primeiro da experiência colonizadora, desenhado como um retumbante fracasso, vinha sendo aos poucos substituído pela pintura de um quadro mais favorável, em que a cidade, em meio à situação de declínio da economia cafeeira em todo estado e, particularmente, na região vizinha de Cantagalo, já aparecia como símbolo de prosperidade, trazida pela estrada de ferro, pelo desenvolvimento do comércio e pelo crescimento urbano.

Seguindo a mesma linha de pensamento inaugurada por Agenor de Roure, no ano de 1919 era publicado o Álbum de Nova Friburgo, livreto editado por Julio Pompeu, que, dando seqüência às comemorações do centenário, apresentava um quadro geral do município, com seus pontos turísticos, praças, ruas, principais estabelecimentos comerciais, colégios, sítios e fazendas, além das personalidades históricas e lideranças políticas de então. A referência à colonização suíça aparecia destacando a ação dos fundadores como essencial para a formação da "cidade civilizada e bela" do presente, uma cidade "singular" dentro do cenário brasileiro. 
Eram realçadas as "virtudes cívicas" do povo helvético e seu "grande amor ao trabalho", símbolos também da singularidade, dando a entender que se tratava de qualidades raras no Brasil de então:

Foi aquele grupo de louros filhos das montanhas, trabalhadores e virtuosos, e os brasileiros, deles nascidos, que, da modesta colônia de criadores e cultivadores, fizeram a cidade civilizada e bela de hoje, essa Friburgo tão singular entre nós, pelos vestígios das raças dos seus fundadores e tão poeticamente encantadora, com o seu aspecto de pequena cidade européia, vestida dos esplendores das nossas matas, do nosso céu e das nossas cachoeiras.

$\mathrm{Na}$ alma dos friburguenses existe ainda uma grande ternura e veneração pelos fundadores da sua urbe ... o núcleo dos inteligentes e tenazes colonizadores, que trouxeram, com um grande amor ao trabalho, um fundo de virtudes cívicas, próprias do povo helvético, e são o patrimônio inextinguível da população de Nova Friburgo.

\section{Suíços $x$ alemães}

Naqueles anos que precederam a década de 1920, no entanto, a existência de uma colônia suíça era praticamente nula entre os friburguenses, além de que a presença dos descendentes dos primeiros colonos suíços restringia-se quase que exclusivamente à das famílias de pequenos proprietários rurais nos distritos, como o de Lumiar. O censo de 1920 indicava existirem apenas 1.475 estrangeiros num total de 28.651 habitantes. Entre os estrangeiros, naquele momento, adquiriam maior importância as colônias italiana e alemã, sem falar nos portugueses e nos negros. O censo de 1872 já havia apontado a existência de 1.081 estrangeiros entre 6.303 habitantes da Vila de Nova Friburgo, na zona urbana do município, assim distribuídos: 595 portugueses, 228 africanos, dos quais 17 livres, 98 alemães, 66 suíços, 37 franceses, 24 espanhóis, 19 italianos etc. (Soares, 1952, p. 7). Italianos e portugueses estavam à frente de vários estabelecimentos comerciais, ao passo que a presença negra se fazia sentir nas ruas da cidade, junto ao comércio ambulante (Guimarães, 1916).

Quanto aos alemães, cuja primeira leva migratória ocorrera em 1824, sua importância para a vida da cidade evidenciava-se na instalação das fábricas, cujo capital empregado foi, basicamente, o alemão. A possibilidade de os alemães influírem nas decisões políticas locais era muito mais efetiva em função do capital econômico de que dispunham, como de fato ocorreu, no momento mesmo da implantação das fábricas. A facção liderada por Galdino, por sinal, seria a grande defensora dos interesses do grupo alemão na arena política municipal. Mas, como demonstra Araújo (1992, p. 215), o prestígio dos germânicos estava em 
baixa justamente por causa do posicionamento da nação alemã durante a Primerira Guerra Mundial na Europa. Era necessário fazer sobressair um outro referente, que não o alemão, como constituidor da população local, para o que os suíços serviram muito bem:

Nesse momento, portanto, teria sido mais interessante ressaltar as origens não alemães da antiga colônia do Morro Queimado. Para isso, o elemento suíço prestaria de forma bastante adequada a construção do ideal de cidade européia montada em pleno seio de um mundo tropical. Nova Friburgo tornar-se-ia um pedaço da Suíça - leia-se, país adiantado, civilizado, moderno - no meio de um mundo dos trópicos, onde predominava uma população de origem portuguesa ou africana - leia-se, regiões atrasadas, não civilizadas.

Esse ponto de vista pode ser comprovado por um artigo publicado no jornal A Cidade de Friburgo, de propriedade do então prefeito Sílvio Rangel, na edição de 8 de maio de 1918, às vésperas das comemorações do centenário do município, que tiveram do veículo uma ampla cobertura. O artigo chegava a referir-se à colônia fundada no século anterior como o próprio "Canaã bíblico", enumerando apenas os aspectos positivos do projeto de colonização, além de incensar como responsáveis pelo "sucesso" do empreendimento as figuras dos suíços, que teriam se adaptado perfeitamente à terra e à nova nacionalidade, em contraposição ao exemplo dos alemães

...A coroação do menino imperador em 1841 viu a antiga colônia transformada num formoso e próspero município, tendo realizado o caldeamento e a conseqüente nacionalização de sua descendência. No transcurso do período romântico, que vai da coroação ao início da guerra contra o Paraguai, Nova Friburgo aparece como um centro laborioso, com exportação de cereais e gêneros de primeira necessidade considerável, progredindo sob os influxos duma população em que a sobriedade de maneiras afirma a existência de uma moral austera. Nunca, nos seus cem anos de existência, a colônia de suíços deu mostras de repugnância à nacionalidade adotiva. Os exemplos de rebeldia e conquista extravagantes estariam reservados às colônias suspeitas dos alemães, que se encaminharam no rumo do sul, quando ninguém conhecia ainda os seus processos secretos...

Como se vê, o retrato dos alemães era pintado de forma oposta ao do dos suíços. Era um discurso que somente fazia sentido em meio à conjuntura da época, ao final da Primeira Guerra Mundial, quando os alemães eram execrados pela opinião pública internacional e nacional. Note-se que, no artigo, não era sequer citada a vinda dos imigrantes alemães para Nova Friburgo, em número de 324, no ano de 1824, 
ocupação organizada pelo ministro José Bonifácio de Andrada e Silva, justamente para tentar reativar a Vila, cuja decadência e esvaziamento já eram evidentes desde o retorno de d. João VI a Portugal, quando cessaram os subsídios reais à colônia.

Essa caracterização extremamente negativa a respeito dos alemães foi sendo construída no desenrolar da guerra, tornando-se mais acintosa a partir de 1916, quando a Alemanha declarou guerra a Portugal, e francamente virulenta em 1917, após o torpedeamento de navios brasileiros por submarinos alemães, o que levou o Brasil a declarar guerra à Alemanha. Por esse motivo, inclusive, o Sanatório Naval de Friburgo, funcionando desde 1910, recebeu, como prisioneiros, 226 oficiais e marinheiros de um navio da marinha mercante alemã, que se encontrava aportado em Recife naquele ano. Os prisioneiros ali ficaram durante o restante da guerra, sendo que alguns deles foram contratados pelas fábricas Ypu e Arp, que aproveitaram seus conhecimentos de administradores e de técnicos em máquinas. Finda a guerra, boa parte deles retornou à Alemanha, mas outros permaneceram em Friburgo, engrossando a colônia alemã já existente. De qualquer forma, a presença dos prisioneiros em Friburgo, naquele momento, só poderia contribuir no sentido da caracterização negativa dos alemães.

Por outro lado, o jornal A Paz, de propriedade de Galdino do Valle Filho, havia se constituído em porta-vOz dos interesses dos donos das fábricas, cujo capital acionário dominante era o alemão. Por extensão, A Pazvinha advogando também a defesa da colônia alemã em Friburgo, o que pode ser verificado através de uma série de artigos favoráveis e, mesmo, simpáticos às ações da Alemanha, quando eclodiu a guerra. Em agosto de 1914, o jornal estampava como manchete principal: "A guerra das potências - A Europa conflagrada - O kaiser, novo Napoleão desafia o mundo", e, num longo artigo, analisava o conflito, buscando situar cada país europeu dentro dele, tendendo, no entanto, a se posicionar de forma favorável aos alemães.

Outras matérias de A Paz teceriam elogios ao kaiser, que, segundo o jornal, não só personificaria a Alemanha em tudo que ela possuía de grandioso e belo, como também teria sido responsável pela criação de um povo de fato, uma nacionalidade forte em todas as manifestações da inteligência humana. O periódico ressaltava não estar fazendo uma ode à guerra, mas prestando uma homenagem ao mentor de uma possante nacionalidade e fazendo jus à colônia alemã da cidade, pelos benefícios que vinha auferindo com seu labor e operosidade à população friburguense. Outro artigo, publicado na edição de 2 de abril de 1916, aludia à presença alemã no Brasil, onde a expansão germânica, depois da América do Norte, mais se fazia notar, através de "indícios vigorosos na raça, nos usos e costumes do Brasil meridional". Quanto a Nova Friburgo, o artigo chegava a afirmar que o município praticamente devia à colônia alemã a sua fundação de fato, porque os primeiros habitantes, de origem suiça, haviam abandonado a cidade à procura 
de melhor fortuna, no interior. A vinda dos alemães, no século XIX, teria sido responsável por evitar o desaparecimento da cidade e por inaugurar o período verdadeiramente progressista de Friburgo.

Quando o governo brasileiro declarou guerra à Alemanha, em novembro de 1917, o jornal A Pazalertaria para o perigo de se atacar indiscriminadamente os alemães residentes em solo pátrio, como os de Friburgo, cujas empresas proporcionariam benefícios à cidade, produzindo benesses e garantindo emprego a centenas de trabalhadores brasileiros. O jornal passava, então, a adotar uma posição defensiva, buscando, de um lado, colocar-se ao lado do governo brasileiro, o que era inevitável naquele instante, e, de outro, preservar a colônia alemã e seu patrimônio material de possíveis retaliações na cidade: "Não é a patriotada barulhenta e arruaceira que atira pedras aos edifícios o que o Brasil precisa e espera de seus filhos nesta emergência horrível", completava.

Enfim, a idealização de Nova Friburgo como a Suíça brasileira terminaria por se configurar extremamente conveniente aos homens políticos de Friburgo naquele momento histórico específico, "varrendo para debaixo do tapete" as contradições sentidas à flor da pele. Os "fantasmas" dos alemães ficavam de fora da "gênese de Nova Friburgo", e todas as energias seriam canalizadas para as comemorações do centenário de fundação da colônia suíça no ano de 1918, dando prosseguimento, então, à definição do município como espaço privilegiado, entre as várias cidades brasileiras, para o desabrochar da "civilização" e do "progresso", por ter, como núcleo fundador, um povo de origem européia. Nada mais propício, portanto, que esse povo viesse a ser o helvético, identificado tão-somente com os ofícios e as artes de manejar as ferramentas de trabalho, jamais as armas de guerra.

\section{REFERÊNCIAS BIBLIOGRÁFICAS}

Araújo, João Raimundo de 1992

Bosi, Alfredo 1993

Chesneaux, Jean 1995

Corrêa, Heloísa Beatriz Serzedello 1985

Ferreira, Marieta de Moraes (org.) 1994
Nova Friburgo: o processo de urbanização da Suiça brasileira. Dissertação de mestrado, Niterói, Universidade Federal Fluminense.

‘A escravidão entre dois liberalismos'. Dialética da colonização. São Paulo, Companhia das Letras.

Devemos fazer tábula rasa do passado? São Paulo, Ática.

Nova Friburgo: o nascimento da indústria (1890-1930). Dissertação de mestrado, Niterói, Universidade Federal Fluminense.

Em busca da idade de ouro.

Rio de Janeiro, Ed. UFRJ/Tempo Brasileiro. 
Ferreira, Marieta de Moraes (org.) 1989

Guimarães, Arthur 1916

Hobsbawm, Eric 1996

Hobsbawm, E. e Ranger, T. 1984

Louzada, Gioconda 1991

Mayer, Jorge Miguel e Pedro, José Carlos s. d.

Nicoulin, Martin 1996

Ortiz, Renato 1985

Pompeu, Julio 1919

Roure, Agenor de 1918a

Roure, Agenor de 1918b

Soares, Décio Monteiro 1952

Jornais
A República na velha província. Rio de Janeiro, Rio Fundo.

Um inquérito social em Nova Friburgo: ensaio de sociologia prática.

Rio de Janeiro, Tipografia do Jornal do Commercio/Departamento Pró-Memória da Prefeitura Municipal de Nova Friburgo.

A era do capital. $5^{\underline{a}}$ ed.,

Rio de Janeiro, Paz e Terra.

A Invenção das Tradições.

Rio de Janeiro, Paz e Terra.

Presença negra: uma nova abordagem de Nova Friburgo. Niterói, EDUFF.

Vida e morte na colônia de Nova Friburgo.

Departamento Pró-Memória da Prefeitura Municipal de Nova Friburgo. (mimeo.)

A gênese de Nova Friburgo.

Rio de Janeiro, Fundação Biblioteca Nacional/Prefeitura Municipal de Nova Friburgo.

'Memória coletiva e sincretismo científico: as teorias raciais do século XIX'.

Cultura Brasileira \& Identidade Nacional. São Paulo, Brasiliense.

Álbum de Nova Friburgo. Petrópolis, Officinas Graphicas L. Silva \&

C. Departamento Pró-Memória da Prefeitura Municipal de Nova Friburgo.

'O centenário de Nova Friburgo'.

Revista do Instituto Histórico Geográfico e Brasileiro, tomo 83.

'A abolição e seus reflexos econômicos'. Revista do IHGB, tomo 83, pp. 315-331.

Terra friburguense. Niterói, Imprensa Oficial/

Departamento Pró-Memória da Prefeitura Municipal de Nova Friburgo.

Disponíveis para pesquisa no Departamento Pró-Memória da Prefeitura Municipal de Nova Friburgo:

A Paz

A cidade de Friburgo

Recebido para publicação em março de 2001.

Aprovado para publicação em junho 2001. 